\title{
Assessing Microbial Sulphur Oxidation Intermediates Cycling in Mine Water Mesocosms
}

\author{
J. GORDON ${ }^{1}$, T. COLENBRANDER NELSON ${ }^{1}$, \\ K. WHALEY-MARTIN ${ }^{1}$, L. TWIBLE $^{1}$, S. KUMAR $^{1}$, \\ A. BOZZO ${ }^{1}$, S.C. APTE ${ }^{2}$, L.A. WARREN ${ }^{1}$ \\ ${ }^{1}$ Department of Civil and Mineral Engineering, University of \\ Toronto, Ontario, Canada \\ ${ }^{2}$ CSIRO Land and Water, NSW, Australia
}

Although the link between the oxidation of sulphur oxidation intermediates (SOIs) and acidity generation in mine wastewaters is well recognized, the complexity of actively managed tailings impoundment systems is a barrier to constraining causal biogeochemical relationships with field data. Here, 8 experimental mesocosms $(500 \mathrm{~L}$ tanks measuring $1.2 \mathrm{~m} \mathrm{x} 0.8 \mathrm{~m}$ ) were used to assess the effects of (i) light and oxygen levels, (ii) $\mathrm{S}_{2} \mathrm{O}_{3}{ }^{2-}, \mathrm{NO}_{3}{ }^{-}$, and $\mathrm{DOC}$ amendments, and (iii) $\mathrm{S}_{2} \mathrm{O}_{3}{ }^{2-}$ vs. $\mathrm{S}_{4} \mathrm{O}_{6}{ }^{2-}$ amendments under 3 sulphur oxidizing bacterial (SoxB) enrichments. Each experiment used tailings wastewater and ran $\sim 4$ weeks. Mesocosms were fitted with probes to continuously monitor physio-chemical parameters $\left(\mathrm{pH}, \mathrm{O}_{2}\right.$, temperature and light), sampled for Org C and S, N, and Fe speciation weekly, and for $16 \mathrm{~S}$ rRNA at $\mathrm{t}=0$ and $\mathrm{t}=\mathrm{end}$.

In experiment 1 , the ambient wastewater $\mathrm{S}_{2} \mathrm{O}_{3}{ }^{2-}$ concentration $\left(\left[\mathrm{S}_{2} \mathrm{O}_{3}{ }^{2-}\right]_{0}=0.2 \mathrm{mM} \mathrm{S}\right)$ decreased by $0.01 \mathrm{mM}$ $\mathrm{S} /$ day irrespective of light or $\left[\mathrm{O}_{2}\right]$ while mesocosms experienced $\mathrm{DO}>18 \%$ and $\mathrm{pH} 4-8$. This rate revealed rapid substrate processing $(\sim 21$ days $)$ by endemic SoxB. In experiment 2, where $\left[\mathrm{S}_{2} \mathrm{O}_{3}{ }^{2-}\right]_{0} \approx 2.0 \mathrm{mM} \mathrm{S}$, the $\mathrm{S}_{2} \mathrm{O}_{3}{ }^{2-}$ concentration decreased following a pseudo-first order reaction $\left(\approx 0.19 \mathrm{day}^{-1}\right)$ at $\mathrm{pH} 4-8$, but rates varied across eacceptor / donor treatments which indicated that these affect $S$ cycling. Experiment 3 demonstrated that an addition of 2.0 $\mathrm{mM} \mathrm{S}$ as $\mathrm{S}_{4} \mathrm{O}_{6}{ }^{2-}$ resulted in a greater net increase in $\left[\mathrm{H}^{+}\right]$, irrespective of SoxB amendments, compared to a $2.0 \mathrm{mM} \mathrm{S}$ as $\mathrm{S}_{2} \mathrm{O}_{3}{ }^{2-}$ addition. Distinct changes in microbial community also occurred with each treatment identifying the interactive importance of SOI speciation and concentration as well as microbial community in determining overall geochemical outcomes in these mining wastewater contexts. 